\title{
Affirmative old age - the ageing body and feminist theories on difference
}

\author{
By LINN SANDBERG*
}

\begin{abstract}
Discourses on old age and ageing are framed in narrow and binary ways, either as a decline narrative or through discourses of positive and successful ageing. The decline narrative, on the one hand, is highly centred on the decline of the ageing body as frail, leaky and unbounded, and on how old age is characterised by non-productivity, increasing passivity and dependency. Discourses on successful ageing, on the other hand, rely heavily on neo-liberal imperatives of activity, autonomy and responsibility. In successful ageing, the specificities of ageing bodies are largely overlooked while the capacity of the old person to retain a youthful body, for example, with the aid of sexuopharmaceuticals, is celebrated. This article argues for the need of a theorising of old age that goes beyond the binaries of decline and success. Drawing on the work of feminist corpomaterialists Rosi Braidotti and Elisabeth Grosz, the article proposes affirmative old age as an alternative conceptualisation of old age.

* Linn Sandberg, Department of Social and Welfare Studies, Unit of Social Work, Linköping University, Linköping, Sweden

An early version of this article was presented as a paper at the BSA Ageing, Body and Society Study Group Conference 'Ageing, Body and Society: Critical Perspectives, Future Challenges', 6 July 2012, the British Library Conference Centre, London, UK.
\end{abstract}


International Journal of Ageing and Later Life

As a theoretical project, affirmative old age aims to acknowledge the material specificities of the ageing body and is an attempt to theorise the ageing body in terms of difference but without understanding it as a body marked by decline, lack or negation.

Keywords: embodiment, feminist theory, affirmative old age, successful ageing, sexuality.

A late November evening when I am still at the office, though it is well past office hours, I receive a phone call from a man who is eager to speak to me. I am in the start-up phase of recruiting participants for my doctoral study on ageing, masculinity, embodiment and sexuality, and I presume the man is interested in participating in the project. But no, he can't, he says. His partner is out of the house and there is something he has to talk to me about before she returns: "I can't get an erection." He is 76 years old and since his previous wife's death he is incapable, he says. At present, he is living with a new partner, a woman seven years younger than him, and he thought he would continue having sex with her, he tells me. But he can't. $\mathrm{He}$ has tried everything but nothing seems to work, and he is very concerned and disappointed:

I hoped it would go on. I want to experience the things I've experienced earlier in life. I'm not enough. My partner should have someone who's younger. A real man.

The anonymous caller clearly links his declining erectile function to his sense of self, and that his inability to have sexual intercourse with his partner deprives him of his masculinity and becomes a loss of masculinity in later life. This narrative reflects a common and persistent discourse on ageing as loss, decline and deprivation (Gullette 1998). At the very heart of this discourse on old age as negation is the ageing body as unbounded, leaky, fragmented and lacking control (Schwaiger 2006). The ageing body has consequently been discussed as a threatening disruption to identity and self (Öberg 2003; Öberg \& Tornstam 1999; see review discussion and critique in Tulle 2008a), something that the narrative of the anonymous caller may be an example of. 
However, the decline discourse has been criticised for reinforcing negative and stereotypical images of later life, and for overlooking experiences of ageing that involve the increasingly healthy and engaged ageing of Western populations. In an attempt to reverse this negative discourse, and to fill old age and ageing with positive content, the concept of successful ageing has been introduced into social gerontology, to subsequently evolve discursively and find its way into policymaking and consumerist culture (Katz 2001/ 2002; Rowe \& Kahn 1987, 1998; Rudman 2006). Notably, the concept is also believed to better fit the new generations of seniors, as they have often been renamed, ageing generations who are understood to be healthier and to have greater economic resources, and who as such have the possibility to live longer and more active later lives (Gilleard \& Higgs 2000).

Still, one of the central problems of discourses of successful ageing, in research as well as widespread elsewhere, is that it does not ultimately challenge the age hierarchy and ageism (Calasanti 2003; Liang \& Luo 2012). Rather, it retains youth and the characteristics of youth as desirable. Successful ageing is generally connoted with terms such as activity, productivity, autonomy - all neo-liberal imperatives of capitalist subjectivity, which are also strongly associated with youth and midlife and the productive phases of the life course (Larner 2000; Rozanova 2010; Rudman 2006). As Toni Calasanti and Neal King (2005: 7) have succinctly put it:

Successful Aging means not aging and not being old because our constructions of old age contain no positive content.

With this argument, successful ageing should perhaps more rightfully be termed successful non-ageing or agelessness. Whereas decline discourses on ageing, on the one hand, are closely tied to negative conceptions of the ageing body as one in decay, successful ageing discourses, on the other hand, largely overlook the specificities of the ageing body and the material processes of ageing (Liang \& Luo 2012).

Old age is consequently bound in a binary discourse as either decline or success. This is clearly illustrated in the case of later-life sexuality. Historically, the predominant discourse on later-life sexuality has been a discourse of decline and of increasing asexuality as one ages, a discourse which remains influential to this day, which is noticeable in the fact that large-scale quantitative research and studies on sexuality have traditionally 
International Journal of Ageing and Later Life

not included people over the age of 60 (or even 50) (Calasanti \& Slevin 2001). Yet alongside this discourse on later-life asexuality exists an increasingly influential discourse on sexuality as lifelong, in which continuing to be sexually active is part of healthy and successful ageing (or non-ageing). Studies are increasingly preoccupied with the sexualities of older people, who are reported to continue to be sexually active and more sexually satisfied (Beckman et al. 2008; Herbenick et al. 2010; Lindau et al. 2007). However, as has been pointed out by feminist ageing scholars, sexuality as lifelong and as part of positive ageing is a markedly masculinist and heterosexual discourse in which most of the focus is placed on restoring men's potential for penile-vaginal penetration (Calasanti \& King 2005; Loe 2004; Potts et al. 2006). There are clearly also both consumerist and medicalisation aspects of this shift, with the market introduction of sexuopharmaceuticals playing a vital role in the rise of the discourse on sexuality as lifelong (Marshall \& Katz 2002).

Not only are discourses on old age as either decline or success narrowly binary; these dual discourses also implicate clearly gendered connotations. Descriptions of the ageing body as a frail, leaky and unbounded body and assertions that old age is characterised by non-productivity and increasing passivity and dependency clearly parallel the characterisations of female bodies and femininity (cf. Schwaiger 2006). However, the buzzwords of successful ageing, such as autonomy, activity, productivity and control over one's health and body clearly parallel conceptualisations of masculinity.

In response to this background, in this article I will argue that there is a need for a terminology and a language regarding old age that goes beyond the gendered binaries of decline and success as well as body/mind dualisms, and that acknowledges the material specificities of the ageing body. I will propose the concept of affirmative old age as an alternative conceptualisation of ageing and later life; this concept was originally developed in my empirical work on ageing masculinity and sexuality, mentioned above, in dialogue with feminist theorising on embodiment, sexual difference and sexuality as proposed by Elisabeth Grosz (1994a, 1994b, 1999) and Rosi Braidotti (1994, 2002). While neither of these theorists specifically deals with ageing and the ageing body, I have found their work useful in thinking about ageing embodiment, something I will expand on in the article. I believe that the gendered connotations of the 
discourses of both decline in ageing and successful ageing call for further engagement with feminist theories in studies of ageing embodiment.

Importantly, the need for new terminology should not be understood as a primarily theoretical pursuit, but as a way of more rightfully reflecting the complex lived experiences of ageing. Although the narrative of the anonymous caller at the beginning of the article suggests that ageing and the changes in the ageing body may involve an experienced loss of self and a threat to masculine/gendered subjectivity, this was not the only or even dominant narrative on ageing, embodiment and sexual subjectivity in my studies. The experiences of later-life sexuality I have encountered in my research cannot be narrowly conceptualised as either experiences of decline and negativity or success stories of bodies that challenge and overcome the changes, frailties and ailments of ageing. The changes in the ageing body could instead provide radical ways of rethinking gender, embodiment and sexuality.

There have been several calls for new concepts and theories for rethinking ageing and later life, particularly among social and cultural gerontologists interested in embodiment and corporeality. Thus, in the following I will discuss some of these propositions as well as how I position affirmative old age in relation to earlier discussions, and what contribution this may make. Subsequently, I will introduce the inspirational theories by feminist corpomaterialists Braidotti and Grosz that have informed affirmative old age. From there, I will elaborate on affirmative old age in relation to two empirical studies I have conducted. The first, mentioned earlier, is a project on ageing, masculinity, embodiment and sexuality in which I interviewed and asked 22 men aged 67-87 to write in "body diaries" about their bodies and sexuality in everyday life. This is a full-fledged qualitative study, and this forms the basis of my doctoral dissertation (Sandberg 2011). The second study is a minor pilot work that remains to be developed, and that focuses on sexuality, embodiment and femininity in relation to the Internet. Five pilot interviews were conducted with women in their 50s who seek sexual relationships on the Internet. Finally, I conclude by claiming that affirmative old age as a theory on ageing embodiment, gender and difference not only reflects the many complex and contradictory narratives on ageing and later life but also ideally could work as social critique in a culture that eradicates difference. 
International Journal of Ageing and Later Life

\section{Critical Gerontological and Feminist Perspectives on Embodiment}

For almost two decades, one of the central pursuits of critical gerontologists has been to critique and criticise the dominance of bio-medical models in understanding ageing and to introduce social and cultural dimensions into our ways of conceptualising ageing (Hazan 1994; Katz 1996). Important work within the field has stressed that, rather than simply being driven by biological processes of ageing, we are just as much "aged by culture" (Gullette 2003). As feminist social gerontologist Julia Twigg has pointed out, however, the emphasis within social gerontology on ageing as a social phenomenon rather than a biological process has tended to leave the ageing body with the natural sciences (Twigg 2004). Twigg and other scholars, such as Emmanuelle Tulle (2008a, 2008b), Pia Kontos (1999, 2003), Clary Krekula (2006) and Cheryl Laz (2003), to name a few, have consequently challenged the tendency within gerontology to reinforce a Cartesian split of body and mind and have instead proposed ways of understanding ageing as embodied, although not in any unitary or determined way.

As a great deal of critical gerontology is inspired by feminist work, it is not surprising that the debates and discussions on embodiment are parallel. The long-standing debate in feminist/women/gender studies on whether the focus on social and cultural aspects of gender has led to the obliteration of the material, lived and fleshy body - for example, in the seminal work of Judith Butler $(1990,1993)$ - clearly parallels discussions within ageing studies on whether the material, ageing body and the facticity of the ageing process are overlooked in social and cultural gerontology (cf. Kontos 1999). ${ }^{1}$ Not even in cases in which the body is specifically turned to has this automatically meant that the ageing body is fully theorised and centred. In Laz's (2003) article on ageing as embodied, for example, the body exists primarily as a means of accomplishing age, and the social and cultural performance of the aged self seemingly takes precedence over the material body.

\footnotetext{
${ }^{1}$ For more recent debates on the omission of materiality in feminist theory by socalled "feminist new materialist" critics, see van der Tuin (2008) and the ensuing response by Ahmed (2008).
} 
It is my understanding that affirmative old age, as a concept seeking to challenge binary understandings of ageing as either decline or success, needs to take its starting point in the facticity of bodily ageing and of the material specificities of the ageing body. The material body should be understood as possessing force and agency to also shape subjectivity and sociality, and not merely as malleable raw material taking shape in sociocultural discursive regimes. My understanding greatly resonates with the discussion by Kontos (1999) on the need to look at ageing embodiment as "local biology," a term she picks up from the work of Margaret Lock:

\footnotetext{
The concept of local biology can specify and enrich the critical strand of gerontological knowledge. It provides a conception of the body as a material phenomenon without eliding its materiality with a fixed biological essence. Corporeal reality can be theorised, capturing the extraordinary dynamic engagement between biological changes, social surroundings and individual cognition. (Kontos 1999: 687)
}

Studies of ageing bodies and sexed bodies are consequently in need of non-binary theorisations, which acknowledge both bodily materiality and how bodies emerge as cultural and symbolic representations. For this purpose, I have found Grosz's conceptualisation of the body as an "open materiality" useful (Grosz 1994b: 191). Grosz theorises the body as neither a culturally inscribed product of the social nor as simply part of biology/ nature. Instead, the body as an open materiality exists as a borderline between the binary poles of the nature/culture dichotomy. To illustrate this understanding of the body, Grosz uses the metaphor of calligraphy to point out that it is not only what is inscribed or the ink used that matters but also in fact the quality of the paper. Based on this analogy she argues that, rather than understanding the body as emerging as "writing on a blank page," it can be conceptualised through a model of etching, "which needs to take into account the specificities of the materials being thus inscribed and their concrete effects in the kind of text produced" (Grosz 1994b: 191). Accordingly, the materiality of the body matters; it "possesses a force and being that marks the very character of representation" (Colebrook 2000: 77).

The strength of Grosz's work is not only her non-binary approach to embodiment but also her theorising of bodily specificities as difference. Grosz (1994a, 1994b, 1999), together with Braidotti $(1994,2002)$, works in a 
International Journal of Ageing and Later Life

tradition which Nina Lykke (2010: 107) refers to as "feminist corpomaterialists," and central to their theorising is the affirmation of the female corporeal specificity and the affirmation of sexual difference. In their theorising on difference, they draw on the philosophical works of Luce Irigaray and Gilles Deleuze. Braidotti (2002) points to the long tradition of dealing with differences in pejorative terms, representing them negatively. While Grosz's and Braidotti's pursuits are primarily concerned with sexual difference, it is also possible to think difference in relation to ageing and old age. Although, as indicated above, there is now a rather significant bulk of literature dealing with ageing embodiment which has been useful in rethinking ageing, there has been little discussion of difference as a way of thinking ageing bodies.

In their recent critique of successful ageing, for example, Liang \& Luo (2012: 329) argue for a shift in social gerontology towards a framework they call "harmonious aging," which theorises ageing "based on an integrated body and mind relationship." I understand the concept of affirmative old age as paralleling many of the aspects of Liang \& Luo's (2012) concept. Like "harmonious aging," affirmative old age seeks to underline the facticity of the ageing body. What I find missing from Liang \& Luo's argument, however, is a discussion on the interconnections of power and difference. By drawing on a feminist theoretical genealogy that also highlights the power asymmetries involved in the eradication of difference, I thus find affirmative old age to be a further contribution to ageing studies.

Similarly to how masculinity and the male body are positioned as the norm in relation to femininity and the female body, the discourse on ageing as decline posits old age and the ageing body as the Other in relation to youth and midlife (that which is desirable and sought after). The differences that come with ageing are thus altogether rejected and rendered abject (this particularly refers to the changes that emerge in the so-called fourth age; cf. Gilleard \& Higgs 2011 and Schwaiger 2006). Although it may seem as if discourses of successful ageing to a greater extent affirm and embrace the differences of ageing, it is rather that these discourses encourage subjects to fight all signs of ageing by remaining active, autonomous and in control (Rozanova 2010; Rudman 2006). Paradoxically, then, the increased emphasis on positive aspects of ageing and old age may not work to fundamentally alter and challenge the decline discourse 
around old age, but instead simply advises old people to escape and overcome the differences of the ageing body by all possible means. This can be related to Braidotti's (2002) discussion of the differences proliferating in late postmodern or advanced capitalism as being "Others" of the Same: "These differences, whether they are large or quantitatively small, are not qualitative and consequently do not alter the logic or power of that Same" (Braidotti 2002: 13) - the "Same" in this case being the youthful, ablebodied subject enmeshed in capitalist productivity.

The alternative proposed by Grosz and Braidotti is subsequently to turn to a version of difference as presented in Deleuzian philosophy, whereby difference is not always bound to negation but is instead understood as a proliferative and productive force: positive difference. ${ }^{2}$ I understand ageing bodies to be a striking example of this kind of proliferative process of differentiation. If one thinks of the ageing of the body as not solely something that happens when one gets old but in fact as a lifelong process, then the ageing body may be seen as set in a constant process of differentiation. Cells in our bodies are constantly changing, being made anew. Many of us grow taller and grow teeth, and throughout life we might lose our hair and teeth. Eventually, if we live, most of us get wrinkles, our hair may turn grey or white, and our joints go stiffer. All these things may be understood as part of a process of becoming in which the body is set. Whereas a bio-medical model has postulated changes of ageing in midlife and beyond as decline, the loss of capacities and functions, it is equally possible to understand these changes as the continuous production of difference.

This argument of the ageing body as positive difference may still seem rather abstract. In the following, however, it is my ambition to present the empirical research I have conducted to more fully illustrate how narratives of sexuality and the ageing body could be analysed from the perspective above, as positive difference. By doing so, I wish to show how affirmative old age is not an abstract theoretical project but is rather part of lived realities. It is worth noting, however, that affirmative old age should not be

\footnotetext{
${ }^{2}$ Positive difference should not be understood in relation to how individuals perceive difference, but rather relates to Deleuze's concept, developed in opposition to structuralism's negative difference. For elaboration, see Colebrook (2002).
} 
International Journal of Ageing and Later Life

understood as a typology, whereby some people may be categorised as embodying affirmative old age while others are not. This would merely reproduce some of the great problems of successful ageing, which by defining the successful agers also partakes in the production of unsuccessful agers, the othering of those who are unwilling or unable to age successfully by being too sedentary, too dependent, too asexual and so on (Irni 2010; Liang \& Luo 2012). ${ }^{3}$ As I will show, the very same person who may experience his or her bodily changes as a loss and threat or challenge to subjectivity, similarly to the anonymous caller in the introduction, may also experience the changes in his or her body as producing something new and unforeseen.

\section{Two Empirical Studies on Ageing, Gender, Sexuality and Embodiment}

As mentioned above, the concept of affirmative old age was developed from my doctoral project on old men and sexuality (see Sandberg 2011). Since the completion of this work, I have continued my work on gender, ageing and sexuality in a pilot project on women, ageing and sexuality on the Internet. ${ }^{4}$ Below I will describe these two projects in terms of recruitment, who the participants were, and the methods of the studies.

In the first study, I conducted in-depth qualitative interviews but also asked men to write about their everyday lives with particular focus on embodiment and sexuality, an explorative qualitative method I have called body diaries (cf. Sandberg 2011). The aim of the study was to explore how sexual subjectivities take shape in relation to masculinity, heterosexuality and old age through the narratives of men themselves. The project also

\footnotetext{
${ }^{3}$ The use of the term affirmative in the concept of affirmative old age could be misleading. Affirmative has as an overtone of the positive, just as much as successful or positive ageing. However, in contrast to positive and successful ageing, which I understand as having emerged within regimes of neo-liberal governmentality, affirmative emerges from the theoretical genealogies in Deleuzian Feminism rather than the (neo-liberal) cult of progress, happiness and positivity (Ahmed 2010).

${ }^{4}$ This is a project in collaboration with Hanna Bertilsdotter Rosqvist, Umeå University, Sweden.
} 
aimed to theoretically expand the existing scholarship on masculinity, on how to think and rethink male embodiment and sexuality through the case of old men. A total of 22 men participated in the study. Some were only interviewed and others only wrote in body diaries, while some participated as both interviewees and diarists. The participants were born between 1922 and 1942, and were between 67 and 87 years of age at the time of the study. All of the men were white and ethnically Swedish, and all identified themselves as heterosexual. All were formally retired, but based on the primary professions they had previously held, both workingclass and middle-class men were represented. A majority of the participants were in a relationship, as either married or non-married. Only six were single, following divorce, separation or bereavement.

The men were recruited through advertising in a Swedish weekly paper; posters at health centres, daycare centres and social venues for seniors; and through a presentation of my work to a senior citizen organisation, with a request for men to participate in my study. The most fruitful channel of recruitment was the advertisement in the paper, through which I came into contact with 12 volunteers. In the advertisement, I briefly stated that I was looking for men above the age of 60 who were interested in being interviewed or keeping a diary as part of my social scientific research on older men's bodies and sexuality.

The interviews were fairly traditional, semi-structured interviews that lasted one to two and a half hours, and took place at the home of the interviewee or at a local restaurant/café or library. Each interview was opened with the question "If you were to describe your body, what would you say?" in order to relate the rest of the interview to the interviewee's own conceptions of his body and let the interviewee himself define and create meanings concerning his body and sexuality. For the body diaries, the men were encouraged to develop their own style and format of writing and to write for at least a week. Some suggestions were given on topics they could write about, such as eating, drinking, sleeping, care, exercising, intimacy and sex. The plan was originally to explore male ageing embodiment in a wider sense, but was subsequently narrowed to focus primarily on sexuality and related themes.

In the second study - on women, ageing, sexuality and the Internet - we recruited interviewees from a Swedish Internet dating site focusing 
International Journal of Ageing and Later Life

primarily on sexual dating (in contrast to sites focusing on romantic relationship dating). After notifying the site owner, we created a user account and approached users who were registered as women and above the age of 50 , through private messages on the site. We presented our project as being on experiences of sexuality and seeking sexual contacts online by women above the age of 50, and asked if the user was willing to participate in an interview. We e-mailed approximately 100 users, of whom 18 replied and five volunteered to participate. The five participants, all in their 50 s, were interviewed over the phone and the interviews lasted $45-75$ minutes. ${ }^{5}$ All interviewees but one were currently in a relationship with a man. Four had previously been in long-term relationships/marriages with men and had children from these relationships. In their late 40 s to early 50 s, they had subsequently divorced and gone online to find new sexual and romantic partners. One woman had not divorced, but was in a long-term marriage in which they had decided to go online to find other couples to have sex with when they were in their late 40s. The interviews were semi-structured and involved themes such as sexuality, desire, sexual health, ageing, embodiment, identity and experiences of using different spaces (on- and offline) for sexual and romantic dating. We were particularly interested in how women experienced the Internet as a sexual geography and how it intersected with experiences of desire, sexuality, ageing and the ageing body. The study participants could be characterised as being parts of various sexual communities of swingers, engaging in partner-swapping and/or group sex, or Bondage \& Dominance/Sadomasochism practice.

The first project is completed and has been discussed in several other publications (Sandberg 2010, 2011, 2012a, 2012b, 2013), whereas the second project is still an unfinished pilot project. Although the latter project is still in its infancy, I have chosen to include and discuss the material here to also explore how affirmative old age could be discussed and understood from the perspective of female ageing, ageing embodiment and sexuality. The aims of both studies have been qualitative, seeking to understand participants' sense-making of ageing, sexuality and embodiment, and

\footnotetext{
${ }^{5}$ Due to a mistake by the researchers, the exact year of birth was only noted on one of the five interviewees (Eva), therefore the exact age of the other four is not stated in the article.
} 
they do not seek to make generalisations from the material. In both studies, I have analysed the material using qualitative thematic analysis (Braun \& Clarke 2006) with some inspiration from poststructuralist and discursive approaches (Søndergaard 2002; Winther-Jørgensen \& Phillips 2000).

\section{From Impotence to Intimacy: Rethinking Male Ageing Embodiment and Sexuality}

Impotence, as implied in the term, is commonly understood as a loss, not only of sexual function but just as much of manhood and as such of personhood altogether (Tiefer 2004). In sexuopharmaceutical advertising as well as in mass media representations, changes in erectile function are discussed as causing major anxiety for men (and for women, as their female partners) (Fergus et al. 2002; Oliffe 2005; Sandberg 2011; Tiefer 2004; Vares et al. 2007). The alternative, as proposed by Pfizer among others, is to restore one's erectile function with the aid of sexuopharmaceuticals, which feeds into the successful ageing solution. The use of a new pathological terminology to describe men's erectile changes, from impotence to erectile dysfunction, marks a shift towards new success discourses, whereby the former "old impotent loser" is now an ageless man with an ailment that can be cured (cf. Marshall \& Katz 2002; Wentzell \& Salmerón 2009).

Although men in my study narrated how erectile changes and sometimes loss of erectile function altogether were experienced as distressful and as a hardship, few of them expressed straightforward wishes to regain their former sexual function or the sexual practices they had engaged in earlier life. Instead, many seemed to hold highly negotiated positions visà-vis their changing bodies, not only when it came to erectile function but to bodily changes overall. Particularly, one narrative was highly salient, and participants repeatedly used it to make sense of their later-life sexual subjectivities: that of the significance of intimacy and touch. When the men's bodies changed due to ageing, and not only in terms of erectile function, several men in my study narrated a (re)discovery of other body parts, practices and pleasures.

The most lucid example of this was the story of 77-year-old Gustav, a very illustrative example I have discussed in other publications as well 
International Journal of Ageing and Later Life

(Sandberg 2012b, 2013). In the interview, Gustav tells me about his experiences of prostate cancer and the hormone treatment he underwent following his diagnosis:

It was a very special experience, this hormone treatment. One part was how it changed my body: my breasts started growing. I thought it was really embarrassing (laughs). It was a real blow to masculinity (laughs).

As breasts were things he associated with women and femininity, his growth of breasts was troubling for his sense of masculinity. However, Gustav continues by describing that, despite this experience of a challenge to his masculinity, his experience of the breasts changed. Through his wife's eyes, he started to see his breasts as fitting and proportionate to his body, and even as a sexual asset:

Gustav: She [his wife] thinks that since I have this big belly, she thinks that if I didn't have the breasts my belly would look [bigger], these breasts (laughs) make up the difference.

Interviewer: So she thinks it's sort of fitting?

Gustav: Yeah, yeah, she thinks so, and also that it's a bit sexy.

Interviewer: Oh, how do you think, or what does she mean by this?

Gustav: Well it's sort of soft and nice, well, they aren't that big.

Interviewer: But does she say she thinks it's sexy?

Gustav: No, but she touches them, [and then] I've realized, I've connected-

Interviewer: So when she touches you, you can feel that this is something she finds attractive sort of?

Gustav: Yes, soft and sensual.

What is initially experienced as a loss of manhood subsequently becomes an opening a new way of experiencing a pair of soft and spongy male breasts. Gustav's story is interesting in how it presents the agency and capacities of ageing bodies to shape new subjectivities and experiences of pleasure. But it is also interesting in how it opens up for ways of rethinking masculinity. Gustav does not start to experience himself as a woman; rather, the categories of man/woman, femininity/masculinity become obsolete - what matters concerning the ageing body is its capacity to produce pleasure. The significance of touch, and the a desire for a wider eroticism that does not limit itself to genital stimulation, is also expressed by 87-year-old Yngve, who is very critical of the sexual content of 
everything today and prefers to talk about the significance of love in his life. During the interview, when asked to explain his views on sexuality, he suddenly asks me "Can I take your hand?" I agree and he takes my hand, holding it around my little finger, and says:

\footnotetext{
Yngve: To walk maybe like this [holding just the finger], with the one you like beside you, that's sexy as hell. But not sexy in the genital way, right? I don't know how to say it really. But those kinds of things have been of great importance to me. Regular sex has had much less importance.

Interviewer: When you say regular sex, what are you thinking of, then?

Yngve: Well to make love to one another. But it's rather touching each other, holding each other, to show each other that you like it and so on. There's too much weight put on the sexual today, and sleeping with each other. That's my opinion.
}

In the interview, Yngve tells me he has been impotent for a couple of years now; thus, one may interpret his stress on eroticism and delicate touch as a narrative of adaptation to his new life circumstances. But instead of starting from the assumption that his way of emphasising the "sexy" sensations of finger touching is a mere compensatory strategy, I suggest thinking through affirmative old age, which leads us to different interpretations. The changes in Yngve's body thus further enable the pleasure and desire of "only" holding hands. The narratives of intimacy and touch presented by Gustav, Yngve and several other participants could then be understood as ways of making the entire body into a site for pleasure, instead of being narrowly located in the erect penis. This is not least expressed in the diary of 67-year-old Holger:

\begin{abstract}
Now that I'm older I have discovered that sex life is not entirely dependent on a man's big firm penis. It is more about what feelings you may convey. A woman may experience orgasms without intercourse or touch of her genitals through fondling. I have many times experienced how sexually active women experienced intense orgasms from a kiss or a hug. If you can convey the feeling to a woman that "You are the most wonderful woman" then there might not be a need for potency-invigorating Viagra, Cialis or other chemical preparations. Joie de vivre, erotic curiosity and freedom from prejudices solve most questions on sexuality, of all ages. It is mostly about what two people want to experience together.
\end{abstract}

In the above extract, Holger clearly positions himself as a considerate and accomplished lover, who knows how to satisfy a woman. In this 
International Journal of Ageing and Later Life

respect, it is a narrative that places him within a fairly traditional and conservative discourse on men as the "doers" of women's sexual pleasure (Plummer 2005). But the narrative also points to the availability of a discourse that decentres not only the penis but the genitals altogether.

Rather than wishing to regain their former body and bodily function, men pointed to the potentials of intimacy and touch, of being together with a partner but without necessarily engaging in penile-vaginal penetration. I argue that these kinds of narratives break with the binary discourses on old age as either decline or successful (non)-ageing, and instead open up for thinking along the lines of affirmative old age, which affirms the differences that ageing bodies produce without understanding them as involving decline or loss.

A central aspect of decline discourses on old age is the link between the ageing body and mortality, the understanding of old age and the ageing body as being in a terminal phase. The rejection/abjection of old age and the ageing body as something horrific is consequently connected to an endemic fear of death and dying (Gilleard \& Higgs 2011). The "appeal" of successful ageing discourses thus apparently lies in their promises of "dodging disease, decline and even death as grim and inevitable states" and the fact that they instead provide positive ideas to an ageing population, as suggested by Rozanova (2010: 220). Just as the promotion of sporting activities may be part of a successful ageing project to evade death (Tulle 2008b), the promotion of continued sexual activity may be part of attempts to, if not dispel, at least postpone death.

In my study on men, one version of making sense of sexuality and sexual desire was clearly thinking of it as something that brought health and vitality to the ageing body. This was expressed by Östen, for example, who greatly emphasised the importance of staying sexually active and claimed that: "a love life adds real vigour to your body really." Yet, to several of the participating men the vulnerability of life and the inevitability of death were also very present experiences, and were not something they could overlook or tried to downplay. The reality of the mortal body was instead something that shaped their experiences of laterlife sexuality. This was clearly the case for Owe, 84 years old, who strongly emphasised the significance of intimacy and touch. He describes how 
sexuality today is no longer about intercourse to him but rather "lying naked together caressing each other's bodies and saying nice and tender words." He also expresses how the sexual and intimate acts today are "more elongated; it could stretch over an entire evening or an entire day." And the intensity and pleasure he experiences in these intimate moments are enhanced by the presence of death, of knowing that life is not going to last forever:

\footnotetext{
Owe: Well, it might not be pleasurable in the same way, but what's pleasurable today is perhaps more valuable than what was pleasurable in adolescence. There's such a different content to it today. Today this pleasant togetherness - you know there's an end to it. Before, like I was saying, there was always another day tomorrow as well. Interviewer: So, knowing that something might end does something to the experience? Owe: That adds another beauty to it all.
}

This quote by Owe suggests that intimacy and touch were not experienced as mere substitutes for intercourse and were not understood primarily as something that brings health and life. Instead, they were experienced as pleasurable activities in their own right, and the proximity of death enhanced feelings and experiences of the sexual/intimate encounter. Lennart, whose wife became ill with cancer a couple of years before the interview, tells of an increasing sexual activity and intimacy as a result of her diagnosis, and describes this by saying "swans sing before they die." Lennart, like Owe, describes how the knowledge that either of them could die is also there with him during the sexual encounter.

Lennart: Both Lena [his wife] and I are of an age where one thinks about what will happen next, who will pass away first and how it will feel not to have somebody to crawl over to during the night.

By never knowing when the intimacy and touch will be disrupted by the coming of death, every caress, every encounter skin to skin, is given particular significance and "beauty," as narrated by Owe and Lennart. These narratives can be understood as adding further dimensions to affirmative old age, as not only the ageing body but also in essence the 
International Journal of Ageing and Later Life

dying body is affirmed as something which makes sexuality meaningful. This can be compared to the argument by Vincent (2006), who criticises the anti-ageing sciences for not enabling an affirmative old age, whereby old age has a value in its own right. Vincent (2006: 693) argues that old age should be seen as valuable as a "summation" or a "rounding off," that life would not be meaningful without the existence of death. Irni (2010: 124) asserts that this is a very compelling argument for an affirmative later life because, she argues, "old age has value in itself and also because of its relation to death, rather than despite it." Similarly, sex and sexuality in later life are meaningful because of death - not in spite of it.

\section{Shaping Female Desirous Online Embodiment in Midlife}

If decline discourses on the ageing male body are largely linked to the loss of erectile function, the ageing female body is marked as one of negativity and loss through pervasive bio-medical discourses on the menopause. As feminist researchers have pointed to, the midlife menopausal female body is primarily positioned as a disharmonious and problematic body and the menopause is constructed as an altogether negative process (Eldén \& Esseveld 2002; Martin 1989). Although feminists have for decades challenged reductive biological accounts and argued for more complex understandings of menopause, based on women's own experiences, these critiques have not had any widespread impact on the understanding of the ageing menopausal and postmenopausal body (Dillaway 2006). The loss associated with the (post)menopausal body is linked not only to the loss of the reproductive capacity but also to the assumed loss of both sexual desirability and sexual desire in midlife women.

However, the recent upsurge in discourses on sexuality as part of successful and healthy ageing has given rise to new understandings of the sexuality of ageing women as well, beyond the long-standing idea of asexuality. In this discourse, life past menopause may be presented as a time of renewed sexual interest (Hinchcliff \& Gott 2008). An illustrative example of this is a series of articles published in the Swedish newspaper Dagens nyheter under the headline "Desire and Longing 50+." In several of these articles, women above the age of 50 describe their rediscovery of sexual pleasure and desire beyond midlife, with quotes like "I never had as good sex as I do today" from Elisabeth, 62, or 57-year-old Karin saying 
"I have also discovered my own body and sex in a new way; when I was younger I had a lot of sexual partners but never felt very much with them." 6 The negative images of the old asexual crone thus to some extent co-exist with new positive images of the "sexy senior" woman, who is assertive, desirous and active (Hinchcliff \& Gott 2008; Vares 2009).

The five women interviewed for our project on ageing, women, sexuality and the Internet all presented a more or less similar narrative on sexuality in midlife as part of the process of development, self-exploration and the (re)discovery of pleasure and desire. Four of the women linked this to their divorces from long-time husbands, whom several had married when they were rather young and sexually inexperienced. Lena describes how sex had previously been more of a marital duty, to keep her man happy, but how the divorce in midlife had brought about a radical shift in her sexual subjectivity:

Lena: Well, during this period when I was single I had a couple of longer relationships, all lovers, "sex buddies," whatever you choose to call them. And I then discovered my sexuality. Had my first orgasm, had my first squirting orgasm. And I just completely enjoyed myself. I could be naked with a man, I could have breakfast naked, I swam naked, the lot.

Eva, 53 years old, describes a similar experience after having divorced the man she had been married to for 30 years. She started to chat with different people on Internet forums, which she found very exciting. This also led her to new sexual experiences online, starting an online relationship with a man who she had webcam sex with, and she learned to discover her own body and what she enjoys:

Eva: I had never touched myself, fondled and discovered myself the way he made me do. He made me try to relax and really like myself. And this was something I'd never really done, I'd always had a hard time accepting myself, putting myself down, and I think that's a typical thing for women, we have problems accepting what we look like, that we're good enough and so on [... . So I learned a lot and let go of a lot, well, and also this thing of doing it myself, I had to satisfy myself as there was no one else. If I didn't do it there'd be nothing.

\footnotetext{
${ }^{6}$ http://www.dn.se/insidan/insidan-hem/ elisabeth-62-jag-har-aldrig-haft-sabra-sex-som-nu
} 
International Journal of Ageing and Later Life

Although men play a significant role in women's journeys towards sexual and bodily self-discovery, as online and offline sexual partners, the women's narratives are still strongly focused on themselves and their increased agency and assertiveness following their divorces in midlife. In this, the Internet is described as an important arena. The online setting becomes an exciting space where the women meet new people outside their everyday sphere, and the excitement is linked not only to sexuality but also to new encounters with people in general. But in contrast to offline encounters, the Internet is experienced as a space where the interviewees are in control and more free from demands. Eva, for example, says:

\footnotetext{
I mean online, I can back off, I can influence this [...] It's free from demands really, you choose yourself when to go there, how far you want things to go and you choose yourself with whom and what. Nobody can get a hold of you, like in everyday life, in physical contact. And this sort of makes it fun, it adds something, it becomes relaxing.
}

Eva's experience resonates with that of Lotta, who speaks of how you can always shut down the webcam if something does not please you and discusses how the online sexual experiences suited her in the particular phase she was in after her divorce:

Lotta: I did it [had online sexual contacts] when I was just recently divorced and didn't want to go out and meet anyone at all, but really wanted to try [and see] if I could be awakened, and [I] was a little interested in sexuality and men, things that had been sort of shut off

A common narrative of the interviewed women is consequently on midlife and beyond as a phase of self-discovery and a renewed or awakened interest in sexuality, after years of family life, children and duties, which had diminished their interest in sexuality, pleasure and desire. It is interesting how the Internet becomes an enabling arena in this process, a space where the women experience themselves as being in control of their own sexual embodiment, in contrast to many other spaces in their everyday lives.

Linking these narratives to the article's discussion of affirmative old age, how then could these women's narratives be understood in these terms? Clearly, the narratives challenge negative decline discourses on the (post)menopausal ageing body as lacking and asexual, to affirm it as a 
site for the production of pleasure and desire. But in terms of successful ageing, the interviews in many ways convey successful ageing discourses whereby the maintained interest in sexuality enables healthy and positive later-life identities. As I pointed to in my discussion on the older men's narratives on sexuality, people's experiences and narratives on ageing may well engage with successful ageing discourses and decline discourses while at the same time opening up to a reading of affirmative old age.

One example from the interviews that I find interesting for thinking and developing affirmative old age is when two of the interviewees, Christina and Eva, speak about their experiences within swinger contexts they have participated in, whereby people for example swap partners and have group sex. Christina describes the swinger context she sometimes participates in as a fairly aged community, in which most are in midlife and beyond, and Eva speaks of "the acceptance" she has experienced within the swinger community, describing the ordinariness and agedness of people's bodies. Eva describes an experience of visiting a swingers' club and how she was positively surprised by how the differences and variations of the ageing bodies in this context were affirmed:

\footnotetext{
Eva: Well, I don't have a model's body. I'm a bit overweight, have scars from surgery on my belly where it's sort of irregular and bumpy. I mean, my body is what it is after overweight and weight loss and two children and all that. But just this thing being desired, desired is a good word in this context, and the openness. [...] There were like fifty women there that night, and among these, being a bit prejudiced, one would have thought that maybe five could show themselves naked. The rest were just ordinary old hags (laughs), butts, big tits and small tits and all that. But this acceptance of our differences was just huge, and the excitement in the group was just ....
}

Rather than being looked upon as unattractive, lacking youthfulness and slenderness, female ageing bodies are described as being capable of producing "excitement," desire and potential pleasure. Similarly, Christina describes how the looks and the surface of the ageing bodies become unimportant in the swinger community:

Christina: You're pretty much forgetting how the body, that's the paradox, you forget how the body is [...] I mean I've been playing with people both younger and older than myself, even people quite a lot younger and, well, at that point you don't care what's good looking and beautiful and firm. Well the body as a surface doesn't matter 
International Journal of Ageing and Later Life

really. Cause it's what you're doing with it that matters. You're pretty much focused on enjoying, and that's something you could do together with anyone who likes it and who's good at it.

Both Eva and Christina discuss the unimportance of what the body looks like in the sexual encounters; what matters instead is its capacity to produce enjoyment and pleasure. Christina repeatedly uses the word "play" to describe the sexual practices she engages in, which points to the experiences of ageing sexual bodies as being capable of creativity. These experiences parallel the words of Kontos (2003: 166) on how "the body can be a source of inventiveness and creativity, inviting us to understand the body as active, that is, imbued with a life force that has its own intentionality." The bodies narrated by the interviewed women are discussed primarily in terms of what they produce, their inventiveness and creativity in terms of pleasure and desire, and how the differences of ageing bodies are affirmed in these sexual encounters. I understand these narratives as being linked to my theoretical premise of affirmative old age on difference not as negation but as something productive. The sexual experiences of the women are not primarily valued for what they produce in terms of health, but are rather made sense of as something disruptive with the potential to change how one experiences oneself. Several of the women discuss how they experience themselves as more open and assertive following their midlife sexual experiences. The creative and exploratory aspects of sexuality can be compared to the discussion by Tulle (2008b: 340) in which she discusses ageing elite runners and how training can be understood as a "creative pursuit in its own right," rather than being framed within a sports-scientific context in which training is a means to fight ageing. The way I propose affirmative old age in this article is thus as a non-teleological concept which focuses less on the outcomes in terms of health, well-being and avoidance of ageing and more on the unbounded production of desire.

\section{Affirmative Old Age and the Affirmation of Difference: Some Concluding Remarks}

In this article, I have proposed the need for an alternative conceptualisation of old age, beyond the binaries of decline and success. By thinking with 
and through feminist theorists' work on difference, I have introduced the concept of affirmative old age as a concept which goes beyond the dialectics of negation, and which affirms the specificities of ageing bodies and highlights the capacities of becoming in ageing bodies and subjectivities. Although critical gerontologists have made significant contributions to challenging the body/mind dualism in ageing studies, I understand difference to be something that needs further attention within the field.

To elaborate on affirmative old age, I have drawn upon two empirical studies I conducted: one on ageing masculinity and sexuality among older men, and another on embodiment, ageing and the Internet with women in midlife. With the study on older men I aimed to show how men's experiences of ageing bodies could neither be reduced to experiences of loss or of erectile or other bodily capacities nor be understood as success stories whereby men resisted ageing and regained their bodies of youth, for example, through sexuopharmaceuticals. Instead, the materiality of the men's ageing bodies directed them towards increasing intimacy and touch, and towards a wider discovery of the body as a whole. The materiality and frailty of the ageing body was, moreover, visible in the men's experiences of illness and death. While death in itself was naturally experienced as a loss, the fact that one was living in proximity to death was not experienced as something that deprived later life of meaning. Instead, some participants affirmed the experiences of death and dying as something that produced greater intensity and value in their lives, not least when being intimate with a partner.

Moreover, in relation to our study on women, I discussed how the menopausal or postmenopausal female body is continuously represented as a problematic and lacking body, deprived not only of reproductive capacity but also of both sexual desire and attractiveness. Emerging representations increasingly depict "the sexy senior woman" with renewed interest in sexuality, but without entirely doing away with discourses on older women as asexual. The women interviewed in our pilot project clearly revealed experiences of midlife as a time of sexual exploration and discovering one's body as desirable and as having the capacity to produce pleasure, not least through masturbation. In their narratives, the Internet functions as an enabler, increasing the midlife body's connectivity and production of pleasure and desire. The women narrated affirmative 
International Journal of Ageing and Later Life

experiences of the difference and diversity of ageing bodies, particularly within sexual subcultures such as swinging contexts. In successful ageing discourses sexuality, such as physical exercise, for example, is valued because of its potential to produce health and well-being, and even as a potential means to resist ageing. However, the experiences of sexuality narrated by our interviewees point to midlife sexual experiences as creative and playful, as means in their own right.

Overall, I understand these narratives of men and women as producing more complex understandings of later-life embodiment, sexuality and gendered subjectivities than those represented in decline or success discourses. The ageing body emerges as one of the differences in the sense that the ways it looks, functions and is experienced are different from earlier in the life course. Yet, these differences are not easily categorised as negative or positive, as signs of decline or success. As I noted at the beginning of the article, decline and success discourses have clear gendered connotations. However, men's and women's experiences of ageing embodiment and later-life sexuality pointed to potentials for rethinking binary gender; thus affirmative old age is also a concept which seeks to recognise the potentials that ageing embodiment may entail for feminist theorising.

In the examples I have presented in this article, the ways affirmative old age comes into play are primarily through corporeal differences of embodied ageing, and there is also a slight overemphasis on the positive and joyful experiences of embodied ageing. However, affirmative old age should be a concept that also affirms pain and vulnerability as experiences of ageing, and which also opens up to experiences of cognitive difference. Here I am, for example, thinking of the possibilities for further theoretical explorations of dementia and the cognitive differences produced thereby. Many experience living with dementia as very negative and distressful, yet it does not have to mean a complete loss of self; it can instead mean the production of a different self, more reliant on embodied consciousness. Following the argument by Kontos (2003), the self of the person with dementia may remain through an embodied consciousness, which continues to be capable of creative and affective expression.

A radical challenge to ageism which positions the youthful body as the desirable body does not come from rejecting or obliterating the difference(s) of ageing, through attempts to position later life as the same of 
youth, but rather through affirming the differences of ageing bodies. A pair of breasts on an older man are reshaped from a threat and a challenge to masculinity into the unforeseen desires of touch. The female postmenopausal body, marked by childbirth and soft from fat, emerges as a desiring machine in the online encounter. Affirmative old age, in contrast to successful ageing, does not aspire to agelessness or attempt to reject and fight old age, but instead seeks a conceptualisation and acceptance of old age in all its diversity, from active to sedentary, from sexually vibrant to sexually indifferent. Affirmative old age is as such ultimately a political force and empowering strategy.

\section{Acknowledgements}

The author thanks Ericka Johnson and Jeff Hearn for their invaluable advice and support as the supervisors of my doctoral work 2006-2011. She also wishes to thank Hanna Bertilsdotter for our exciting collaboration on the project on ageing women, sexuality and the Internet.

\section{Corresponding Author}

Linn Sandberg, Department of Social and Welfare Studies, Unit of Social Work, Linköping University, SE-601 74 Norrköping, Sweden. Email: linn.sandberg@liu.se

\section{References}

Ahmed, S. (2008). Open forum imaginary prohibitions: Founding gestures of the 'New Materialism': Some preliminary remarks. European Journal of Women's Studies 15(1): 23-39.

Ahmed, S. (2010). Killing joy: Feminism and the history of happiness. Signs 35(3): 571-594.

Beckman, N., Waern, M., Gustafson, D. \& Skoog, I. (2008). Secular trends in self reported sexual activity and satisfaction in Swedish 70 year olds: Cross sectional survey of four populations, 1971-2001. BMJ 337(a279): $1-7$.

Braidotti, R. (1994). Nomadic Subjects: Embodiment and Sexual Difference in Contemporary Feminist Theory. New York: Columbia University Press. 
International Journal of Ageing and Later Life

Braidotti, R. (2002). Metamorphoses: Towards a Materialist Theory of Becoming. Cambridge: Polity Press.

Braun, V. \& Clarke, V. (2006). Using thematic analysis in psychology. Qualitative Research in Psychology 3(2): 77-101.

Butler, J. (1990). Gender Trouble: Feminism and the Subversion of Identity. London: Routledge.

Butler, J. (1993). Bodies that Matter: On the Discursive Limits of "Sex". New York: Routledge.

Calasanti, T. (2003). Theorizing age relations. In S. Biggs, A. Lowenstein \& J. Hendricks (eds.), The Need for Theory: Critical Approaches to Social Gerontology (pp. 199-218). Amityville, NY: Baywood.

Calasanti, T. \& King, N. (2005). Firming the floppy penis: Class and gender relations in the lives of old men. Men and Masculinities 8(1): 3-23.

Calasanti, T. \& Slevin, K. (2001). Gender, Social Inequalities and Aging. Oxford: Altamira Press.

Colebrook, C. (2000). From radical representations to corporeal becomings: The feminist philosophy of Lloyd, Grosz and Gatens. Hypatia 15(2): 76-93.

Colebrook, C. (2002). Understanding Deleuze. Crows Nest: Allen \& Unwin.

Dillaway, H. E. (2006). When does menopause occur, and how long does it last? Wrestling with age- and time-based conceptualizations of reproductive aging. NWSA Journal 18(19): 31-60.

Eldén, S. \& Esseveld, J. (2002). Frånvarande kvinnliga subjekt - en analys av medicinska texter om klimakteriet [Absent female subjects - an analysis of medical text on the menopause]. Kvinnovetenskaplig tidskrift 23(2-3): 45-59.

Fergus, K., Gray, R. \& Fitch, M. (2002). Sexual dysfunction and the preservation of manhood: Experiences of men with prostate cancer. Journal of Health Psychology 7(3): 303-316.

Gilleard, C. \& Higgs, P. (2000). Cultures of Ageing: Self, Citizen and the Body. Harlow: Prentice Hall.

Gilleard, C. \& Higgs, P. (2011). Ageing abjection and embodiment in the fourth age. Journal of Aging Studies 25(2): 135-142.

Grosz, E. (1994a). A thousand tiny sexes: Feminism and rhizomatics. In C. Boundas \& D. Olkowski (eds.), Gilles Deleuze and the Theatre of Philosophy (pp. 187-209). London: Routledge. 
Grosz, E. (1994b). Volatile Bodies: Toward a Corporeal Feminism. Indianapolis: Indiana University Press.

Grosz, E. (1999). Thinking the new: Of futures yet unthought. In E. Grosz (ed.), Becomings: Explorations in Time, Memory, and Futures (pp. 15-28). Ithaca, NY: Cornell University Press.

Gullette, M. M. (1998). Midlife discourses in twentieth-century United States: An essay on the sexuality, ideology, and politics of 'middleageism'. In R. A. Shweder (ed.), Welcome to Middle Age! (And Other Cultural Fictions) (pp. 3-44). Chicago: University of Chicago Press.

Gullette, M. M. (2003). Aged by Culture. Chicago: University of Chicago Press.

Hazan, H. (1994). Old Age: Constructions and Deconstructions. Cambridge: Cambridge University Press.

Herbenick, D., Reece, M., Schick, V., Sanders, S. A., Dodge, B. \& Fortenberry, J. D. (2010). Sexual behavior in the United States: Results from a national probability sample of men and women ages 14-94. Journal of Sexual Medicine 7(s5): 255-265.

Hinchcliff, S. \& Gott, M. (2008). Challenging social myths and stereotypes of women and aging: Heterosexual women talk about sex. Journal of Women \& Aging 20(1/2): 65-81.

Irni, S. (2010). Ageing Apparatuses at Work: Transdisciplinary Negotiations of Sex, Age and Materiality. Dissertation. Åbo: Åbo Akademi.

Katz, S. (1996). Disciplining Old Age: The Formation of Gerontological Knowledge. Charlottesville: University Press of Virginia.

Katz, S. (2001/2002). Growing older without aging? Positive aging, antiageism and anti-aging. Generations Winter 25(4): 27-32.

Kontos, P. (1999). Local biology: Bodies of difference in ageing studies. Ageing \& Society 19(6): 677-689.

Kontos, P. (2003). "The painterly hand": Embodied consciousness and Alzheimer's disease. Journal of Aging Studies 17(2): 151-170.

Krekula, C. (2006). Kvinna i ålderskodad värld: om äldre kvinnors förkroppsligade identitetsförhandlingar [Women in an Age-coded world: On older women's embodied identity negotiations]. Dissertation. Uppsala: Swedish Universities.

Larner, W. (2000). Neo-liberalism: Policy, ideology, governmentality. Studies in Political Economy 63: 5-25. 
International Journal of Ageing and Later Life

Laz, C. (2003). Age embodied. Journal of Aging Studies 17(4): 503-519.

Liang, J. \& Luo, B. (2012). Toward a discourse shift in social gerontology: From successful aging to harmonious aging. Journal of Aging Studies 26(3): 327-334.

Lindau, S. T., Schumm, P., Laumann, E., Levinson, W., O'Muircheartaigh, C. \& Waite, L. (2007). A study of sexuality and health among older adults in the United States. New England Journal of Medicine 357(8): 762-774.

Loe, M. (2004). Sex and the senior woman: Pleasure and danger in the Viagra era. Sexualities 7(3): 303-326.

Lykke, N. (2010). Feminist Studies: A Guide to Intersectional Theory, Methodology and Writing. New York: Routledge.

Marshall, B. \& Katz, S. (2002). Forever functional: Sexual fitness and the ageing male body. Body \& Society 8(4): 43-70.

Martin, E. (1989). The Woman in the Body: A Cultural Analysis of Reproduction. Milton Keynes: Open University Press.

Öberg, P. (2003). Images versus experience of the aging body. In \& C. Faircloth (ed.), Aging Bodies: Images and Everyday Experience (pp. 103-139). Walnut Creek, CA: Altamira Press.

Öberg, P. \& Tornstam, L. (1999). Body images of men and women of different ages. Ageing and Society 19(5): 629-644.

Oliffe, J. (2005). Constructions of masculinity following prostatectomyinduced impotence. Social Science \& Medicine 60(10): 2249-2259.

Plummer, K. (2005). Male sexualities. In M. Kimmel, J. Hearn \& R.W. Connell (eds.), Handbook of Studies on Men and Masculinities (pp. 178-193). Thousand Oaks, CA: Sage.

Potts, A., Grace, V., Vares, T. \& Gavey, N. (2006). Sex for life? Men's counter stories on 'erectile dysfunction', male sexuality and ageing. Sociology of Health and Illness 28(3): 306-329.

Rowe, J. \& Kahn, R. (1987). Human aging: Usual and successful. Science 237(4811): 143-149.

Rowe, J. \& Kahn, R. (1998). Successful Ageing. New York: Pantheon Books.

Rozanova, J. (2010). Discourse of successful aging in The Globe \& Mail: Insights from critical gerontology. Journal of Aging Studies 24(4): 213-222.

Rudman, D. L. (2006). Shaping the active autonomous and responsible modern retiree: An analysis of discursive technologies and their 
links with neo-liberal political rationality. Ageing and Society 26(2): 181-201.

Sandberg, L. (2010). Lita till lusten?: heterosexuella äldre män och innebörder av lust [In Lust we Trust? Heterosexual Older Men and Meanings of Desire]. In F. Ambjörnsson \& M. Jönsson (eds.), Livslinjer. Berättelser om ålder, genus och sexualitet [Life Lines: Narratives on Age, Gender and Sexuality] (pp. 51-73). Stockholm: Makadam.

Sandberg, L. (2011). Getting Intimate: A Feminist Analysis of Old Age, Masculinity \& Sexuality. Dissertation. Linköping: Linköpings universitet.

Sandberg, L. (2012a). Bortom ståndet, närmare beröringen: möten mellan Irigaray och den åldrande manskroppen [Beyond the erection, closer to touch: encounters between Irigaray and the ageing male body]. Tidskrift för genusvetenskap (3): 61-85.

Sandberg, L. (2012b). "Man har ju lärt sig ett och annat": äldre män och berättelser om sexualitet, mognad och förändring [You've Learnt One or Two Things: Older Men and Narratives on Sexuality, Maturity and Change]. In L. Gottzén \& R. Jonsson (eds.), Andra män: Maskuliniteter, normskapande och jämställdhet [Other Men: Masculinity, Constructions of Norms and Gender Equality] (pp. 45-63). Malmö: Gleerups.

Sandberg, L. (2013). “'Just feeling a naked body close to you': Men, sexuality and intimacy in later life", Sexualities 16(3/4): 261-282.

Schwaiger, L. (2006). 'To be forever young?' Towards reframing corporeal subjectivity in maturity. International Journal of Ageing and Later Life 1(1): $11-41$.

Søndergaard, D.-M. (2002). Poststructuralist approaches to empirical analysis. Qualitative Studies in Education 15(2): 187-204.

Tiefer, L. (2004). Erectile dysfunction. In M. Kimmel \& A. Aronson (eds.), Men and Masculinities: A Social, Cultural, and Historical Encyclopedia (pp. 254-257). Santa Barbara, CA: ABC-CLIO.

Tuin van der, I. (2008). Third wave materialism. New feminist epistemologies and the generation of European women's studies. $\mathrm{PhD}$ Dissertation. Utrecht: Utrecht University.

Tulle, E. (2008a). The ageing body and the ontology of ageing: Athletic competence in later life. Body \& Society 14(3): 1-19. 
International Journal of Ageing and Later Life

Tulle, E. (2008b). Acting your age? Sports science and the ageing body. Journal of Aging Studies 22(4): 340-347.

Twigg, J. (2004). The body, gender and age: Feminist insights in social gerontology. Journal of Aging Studies 18(1): 59-73.

Vares, T. (2009). Reading the 'Sexy Oldie': Gender, age(ing) and embodiment. Sexualities 12(4): 503-523.

Vares, T., Potts, A., Gavey, N. \& Grace, V. (2007). Reconceptualising cultural narratives of mature women's sexuality in the Viagra era. Journal of Ageing Studies 21(2): 153-164.

Vincent, J. (2006). Ageing contested: Anti-ageing science and the cultural construction of old age. Sociology 40(4): 681-698.

Wentzell, E. \& Salmerón, J. (2009). You'll 'Get Viagraed': Mexican men's preference for alternative erectile dysfunction treatment. Social Science E Medicine 68(10): 1759-1765.

Winther-Jørgensen, M. \& Phillips, L. (2000). Diskursanalys som teori och metod [Discourse analysis as theory and method]. Lund: Studentlitteratur. 